\title{
Level of Teachers' Skills in the Implementation of al-Quran Teaching Formative Assessment in Religious Schools in Brunei Darussalam
}

\section{Tahap Kemahiran Guru terhadap Pelaksanaan Pentaksiran Formatif Pengajaran al-Quran di Sekolah-Sekolah Ugama Negara Brunei Darussalam}

\author{
Roslan Untong $^{1 *}$, Misnan Jemali ${ }^{1}$, Norwati Abu Bakar ${ }^{1}$ \\ ${ }^{1}$ Fakulti Pendidikan, KUPU SB, BRUNEI \\ *Corresponding Author \\ DOI: https://doi.org/10.30880/jstard.2020.02.03.015 \\ Received 30 September 2020; Accepted 30 November 2020; Available online 31 December 2020
}

\begin{abstract}
Formative assessment in the teaching of the Qur'an is important to build a comprehensive and continuous potential to master the reading of the Qur'an among religious school students. However, the problem that exists is the extent to which teachers' skills in implementing formative assessment of Quranic teaching in religious schools in Brunei Darussalam. The objective of this study is to examine the skills of teachers in implementing Formative Assessment of Quranic teaching in religious schools in NBD. This study uses quantitative methods using a questionnaire involving a total of 201 teachers from 37 religious schools in Brunei Darussalam. The findings of this study show that Quran teachers in religious primary schools in Brunei Darussalam have moderately high skills (mean $=3.83$ ) in terms of teacher skills related to the concept of formative assessment. This data shows that the skills of teachers in formative assessment during Teaching and learning al-Quran in terms of giving feedback to improve student learning in al-Quran is high (mean $=3.83$ ). While the aspect of teacher skills related to planning formative assessment activities to be applied in the process of teaching and learning al-Quran is low but still at a moderately high level (mean $=3.26$ ). This study presents an important finding that shows the efforts that have been carried out by the Department of Islamic Studies and District Islamic Studies Officers by providing skills to religious school teachers with courses related to strong basic concepts in the formative assessment required by teachers- Quran teacher, to be able to distinguish between formative and summative practices. In conclusion, this study found that overall, the level of teachers' skills in formative assessment during the implementation of Quranic teaching is at a moderately high level.
\end{abstract}

Keywords: Teacher skills, formative assessment, Quran teaching, implement 
Abstrak: Pentaksiran formatif dalam pengajaran al-Quran adalah penting untuk membina potensi secara menyeluruh dan berterusan untuk menguasai membaca al-Quran dalam kalangan murid sekolah ugama. Namun, permasalahan wujud adalah sejauh manakah kemahiran guru dalam melaksanakan pentaksiran formatif pengajaran al-Quran di sekolah-sekolah ugama di Negara Brunei Darussalam. Objektif kajian ini bertujuan adalah mengkaji kemahiran guru dalam melaksanakan Pentaksiran Formatif pengajaran al-Quran di sekolah ugama di NBD. Kajian ini menggunakan kaedah kuantitatif dengan menggunakan soal selidik yang melibatkan seramai 201 orang guru dari 37 buah sekolah ugama di Negara Brunei Darussalam. Dapatan kajian ini menunjukkan bahawa guru al-Quran di sekolah rendah ugama di Negara Brunei Darussalam mempunyai kemahiran sederhana tinggi (min=3.83) dari aspek kemahiran guru berkaitan konsep pentaksiran formatif. Data ini menunjukkan kemahiran guru dalam pentaksiran formatif semasa PdP al-Quran pada aspek memberi maklum balas untuk meningkatkan pembelajaran murid dalam al-Quran adalah tinggi (min=3.83). Manakala aspek kemahiran guru berkaitan dengan merancang aktiviti pentaksiran formatif untuk diaplikasikan dalam proses PdP al-Quran adalah rendah tetapi masih pada tahap sederhana tinggi $(\min =3.26)$. Kajian ini memaparkan satu dapatan penting yang menunjukkan usaha-usaha yang telah dijalankan oleh pihak Jabatan Pengajian Islam dan Pegawai Pengajian Islam Daerah dengan memberikan kemahiran kepada guru-guru sekolah ugama dengan kursus-kursus berkaitan konsep asas yang kukuh dalam pentaksiran formatif yang diperlukan oleh guru-guru al-Quran, agar dapat membezakan antara amalan-amalan bersifat formatif dan sumatif. Kesimpulannya, kajian ini mendapati bahawa pada keseluruhannya, tahap kemahiran guru dalam pentaksiran formatif semasa pelaksanaan pengajaran al-Quran adalah pada tahap yang sederhana tinggi.

Kata Kunci: Kemahiran guru, pentaksiran formatif, pengajaran al-Quran

\section{Pengenalan}

Pentaksiran formatif dalam pengajaran al-Quran merupakan penilaian yang dilaksanakan secara tidak formal dan formal bergantung kepada keperluan guru dan murid. Ianya dilaksanakan secara berterusan sepanjang atau selepas proses pengajaran dan pembelajaran (PdP) atau sesi persekolahan murid bagi menilai penguasaan murid terhadap beberapa kemahiran al-Quran yang diajar. Secara tidak langsung, PF membantu guru mengenalpasti tahap penguasaan murid terhadap sesuatu kemahiran-kemahiran al-Quran yang diajar sebelum meneruskan proses pembelajaran seterusnya. Kelemahan yang dikenalpasti ini boleh diperbaiki dan dipertingkatkan dalam pendekatan pengajaran alQuran sebagaimana yang dinyatakan Allah dalam surah al-Qiyāmah.

Firman Allah Subḥānahu Wa Ta’ālā:

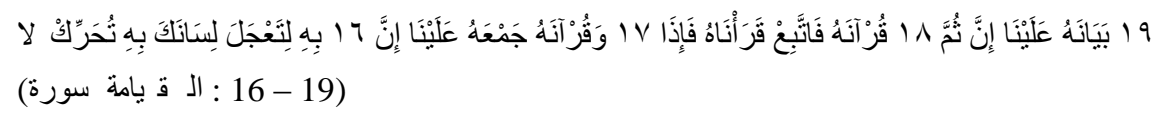

Tafsirnya:

"Janganlah engkau (wahai Nabi Muhammad) menggerakkan lidahmu (membaca al-Quran sebelum malaikat Jibrǐl 'alaihis salām selesai membacakannya kepadamu) kerana hendak segera menghafaznya. Sesungguhnya Kamilah yang mengumpulkan al-Quran itu (dalam dadamu) dan (menjadikan engkau pandai) membacanya. Maka apabila Kami telah selesai membacakannya, ikutlah bacaan itu. Kemudian sesungguhnya Kamilah yang akan menjelaskannya."

(Surah al-Qiyāmah : 16 - 19)

Pentaksiran formatif memberi penekanan utama untuk meningkatkan lagi pembelajaran murid dan dengan harapan dapat membina potensi murid secara lebih menyeluruh (Na'imah, 2011). Pentaksiran formatif dijalankan secara berterusan, diintegrasikan dalam PdP dengan tujuan agar aspek pengukuran murid juga lebih bersifat menyeluruh. Penggunaan teknik pentaksiran formatif yang tepat adalah penting kerana ia membantu murid menguasai apa yang diajar, memberi peluang mereka berkomunikasi, mempamerkan kefahaman serta memenuhi keperluan murid untuk meningkatkan pembelajaran mereka (Black \& William,1998) dan berupaya memberi maklumat kepada murid berkaitan tahap pembelajaran semasa, arah meningkatkan pencapaian serta status pencapaian berbanding objektif pembelajaran (Chappuis \& Chappuis, 2008). Penggunaan teknik PF turut membekalkan maklumat berkaitan kualiti pengajaran guru (Hall \& Burke, 2003). Walau bagaimanapun maksud teknik pentaksiran harus difahami sebaik mungkin supaya tidak membataskan penggunaannya dan kefahaman terhadapnya. Hal ini kerana persoalan berkaitan teknik PF muncul dalam beberapa istilah seperti reka bentuk (Brookhart, 2007), teknik, alat dan aktiviti (Pinchock \& Brandt, 2009) yang merujuk sebagai aktiviti yang digunakan dalam proses mentaksir.

Prestasi pelajar di dalam ujian pembacaan al-Quran berdasarkan markah atau gred tidak dapat menjawab tahap penguasaan pembacaan al-Quran yang dicapai (Roslan et.al, 2011). Dengan kata lain, pencapaian yang ditunjukkan oleh seorang pelajar yang mendapat gred tertentu dari segi kemahiran membaca al-Quran adalah kurang jelas. 
Sepatutnya, gred yang diperolehi oleh pelajar hendaklah menggambarkan kebolehan sebenar atau kekurangan yang perlu diatasi oleh pelajar berkenaan (Roslan dan Manan, 2014). Apa yang penting ialah sekumpulan pelajar yang mendapat markah sama akan mengetahui kekurangan yang sama perlu diatasi untuk meningkatkan mutu bacaan masing-masing. Dengan kata lain, seorang pelajar sepatutnya tahu apa yang perlu dilakukannya untuk meningkatkan kualiti bacaannya berdasarkan gred atau markah yang diperolehinya. Oleh itu, satu kaedah menilai kemahiran membaca al-Quran yang mengambil kira kebolehan sebenar yang boleh ditunjukkannya oleh gred atau markah yang diperolehi adalah lebih bermakna. Dengan demikian, untuk menilai mutu pembacaan al-Quran dengan adil, elemen kemahiran menguasai tajwid serta kefasihan perlu diberi pertimbangan terperinci, iaitu penilai perlu mempunyai kaedah mentaksir setiap jenis kemahiran yang menyumbang kepada mutu sesuatu pembacaaan.

Pentaksiran berasaskan peperiksaan telah mengarah pelajar belajar dan menghafal untuk lulus peperiksaan. Pengetahuan yang diterima tidak akan kekal, malah tahap penguasaan pelajar terhadapnya kurang memuaskan. Ini bermaksud kejayaan dalam peperiksaan kurang menggambarkan kejayaan sebenar penguasaan pelajar terhadap pembelajaran termasuk pembelajaran al-Quran. Isu-isu yang wujud dalam pembelajaran al-Quran sekolah-sekolah ugama di Brunei terdiri daripada aspek kelayakan akademik dan ikhtisas guru-guru, pengetahuan tentang ciri-ciri pelajar dan kebolehan serta kesediaan guru melaksanakan pentaksiran untuk pembelajaran al-Quran.

Apakah sebenarnya pentaksiran untuk pembelajaran (atau disebut sebagai pentaksiran formatif). Menurut Roslan, Misnan dan Noor Shah (2017), ada segelintir guru al-Quran menjelaskan belum dapat memahami konsep pentaksiran sumatif dan pentaksiran formatif. Namun, guru-guru al-Quran lebih menumpukan kepada pentaksiran terhadap pembelajaran berbanding pentaksiran untuk pembelajaran iaitu guru lebih menumpukan pemberian markah serta pengkategorian pelajar dan kurang mengutamakan aspek pembaikpulihan pengajaran dan menggalakkan pembelajaran pelajar. Ini menunjukkan betapa kurang keprihatinannya guru terhadap pentaksiran untuk pembelajaran (Stiggins, 2004, Black dan Wiliam, 1998 dan; Azhar dan Shahrir, 2007).

Dalam hubungan ini, hasil dapatan kajian Azhar dan Shahrir (2007) mendapati sebilangan besar guru kurang menggunakan sepenuhnya maklum balas daripada pentaksiran semasa proses PdP di bilik darjah untuk membantu pembelajaran pelajar, menilai keberkesanan pelbagai kaedah pengajaran guru dan sebagai satu mekanisme untuk melaksanakan penambaikan terhadap pengajaran guru. Implikasi amalan guru ini telah menjadikan pelajar yang lemah akan terus tercicir, tertinggal dan diketepikan, kelemahan pengajaran guru kurang diberi penekanan ke arah pembaikan dan guru tendensi untuk meletakkan kekurangan kepada pelajar mereka apabila keputusan peperiksaan kurang memuaskan.

Justeru, guru-guru al-Quran perlu mempunyai kemahiran mengajar yang sesuai dengan keperluan pembelajaran pelajar mengikut kategori pelajar. Walaupun guru-guru telah mengikuti kursus pentaksiran tetapi mereka masih kurang yakin dalam amalan mentaksir pelajar. Hal ini disebabkan mereka kurang latihan, pengetahuan, kemahiran dalam melaksanakan pentaksiran.

Meskipun guru-guru telah mengikuti pelbagai kursus, baik secara in-house dan jangka pendek, namun masih ada yang kurang yakin dalam mentaksir pelajar. Kekurangan pengetahuan, kemahiran dan sumber bahan menambahkan lagi ketidakyakinan mereka dalam melaksanakan pentaksiran. Tambahan lagi guru-guru tidak dibekalkan dengan sumber bahan seperti garispanduan menilai bacaan pelajar, manual menilai atau mentaksir pelajar, contoh instrumen, contoh pemarkahan, contoh memberikan maklum balas dan sebagainya. Guru-guru al-Quran beranggapan mereka mempunyai kompetensi yang kurang dalam melaksanakan pentaksiran untuk pembelajaran al-Quran (PUPaQ). Keadaan ini berlaku disebabkan oleh beberapa perkara, antaranya; kurangnya bimbingan pentaksiran berfokus kepada PUPaQ dan guru-guru kurang mahir serta pengetahuan dalam menilai secara berkesan berkaitan dengan PUPaQ. Ini menunjukkan bahawa guru menghadapi masalah dalam melaksanakan PUPaQ di bilik darjah masing-masing disebabkan kurangnya ilmu dan kemahiran dalam bidang pentaksiran.

Dalam kajian yang dilaksanakan ini, pengkaji mengkaji sejauhmanakah tahap kemahiran guru al-Quran dalam melaksanakan PF pengajaran al-Quran di sekolah ugama.

\section{Sorotan Karya}

Kebawah Duli Yang Maha Mulia Paduka Seri Baginda Sultan Haji Hassanal Bolkiah Mu'izzaddin Waddaulah, Sultan dan Yang Di-Pertuan Negara Brunei Darussalam bertitah menekankan supaya perhatian berat terhadap al-Quran hendaklah diteruskan melalui cara berterusan memikir, merancang dan melaksanakan program-program yang bersesuaian. Baginda juga menekankan peri mustahak difikirkan mengenai bagaimana cara untuk meningkatkan keberkesanan mata pelajaran al-Quran di sekolah-sekolah ugama memandangkan pencapaian bacaan al-Quran di sekolah-sekolah ugama pada masa ini masih di tahap yang memerlukan pembaikan dan peningkatan (Petikan Titah Pada Majlis Musabaqah Membaca Al-Quran Bahagian Dewasa Peringkat Akhir Kebangsaan pada hari Khamis, Malam Jumaat, (Malam Ketiga), di Pusat Persidangan Antarabangsa, Berakas 13 Rejab 1437 Hijrah/21 April 2016 Masihi).

Pentaksiran formatif pengajaran al-Quran di sekolah ugama di NBD adalah berdasarkan Sistem Pengajaran AlQuran Berkategori (SPAQB) yang dilaksanakan pada tahun 1999 (Garispanduan Pelaksanaan Sistem Pengajaran alQuran Berkategori (SPAQB), 2006). Pelaksanaan Sistem Pengajaran Al-Quran Berkategori (SPAQB) merupakan salah satu cara pentaksiran untuk pembelajaran (pentaksiran formatif) pengajaran al-Quran berasaskan sekolah yang 
dilaksanakan secara berkumpulan dalam menguasai bahan pengajaran yang diberikan oleh guru. Ia adalah merupakan kerjasama yang dilakukan oleh pelajar dalam satu kumpulan kecil yang melibatkan semua ahli di dalam tugas yang diberikan dengan penyeliaan dan pemantauan guru secara langsung.

Pelaksanaannya menghendaki pelajar belajar bersama-sama dalam menyiapkan satu tugasan bagi setiap kumpulan. Ahli kumpulan akan saling bantu-membantu memberi penerangan sesama mereka dan tanpa bergantung kepada guru. Guru akan memberikan pujian ke atas kumpulan yang menunjukkan hasil kerja yang memuaskan. Dalam hal ini, pencapaian seorang pelajar bergantung kepada pencapaian rakan sekumpulan. Sebaliknya, di dalam pembelajaran individu, pencapaian seorang pelajar tidak bergantung kepada pencapaian pelajar lain. Interaksi sesama pelajar diberikan tumpuan dalam SPAQB semasa proses pembelajaran. Secara umumnya, ia merupakan satu strategi pembelajaran berkumpulan yang mana di dalamnya pelajar berinteraksi sesama mereka dan saling bantu-membantu di dalam proses pembelajaran.

Berdasarkan perbincangan di atas jelas menunjukkan bahawa Sistem Pengajaran Al-Quran Berkategori (SPAQB) menyediakan banyak ruang lingkup pembelajaran al-Quran dan memainkan peranannya dalam memantapkan pengajaran al-Quran secara menyeluruh di negara ini. Namun fokus kajian ini ialah menilai bagaimana tahap kemahiran guru dalam pelaksanaan pentaksiran formatif di sekolah-sekolah ugama di NBD.

\section{Metodologi}

Kajian ini dijalankan dengan menggunakan kaedah kuantitatif dimana pengkaji melaksanakan menggunakan soal selidik yang melibatkan seramai 201 orang guru al-Quran dari 37 buah sekolah ugama di Negara Brunei Darussalam. Penentuan kriteria guru adalah berdasarkan penerimaan umum bahawa guru yang telah disahkan dalam perkhidmatan adalah guru yang benar-benar terlatih dan matang. Pengalaman mengajar al-Quran di sekolah diperlukan supaya guru mempunyai keupayaan dan maklumat untuk melaksanakan PF pengajaran al-Quran yang dijalankan di sekolah. Secara langsung dapatan kajian ini dapat sedikit sebanyak menggambarkan situasi sebenar yang berlaku dalam kalangan guru al-Quran di Negara Brunei Darussalam.

\section{Dapatan Kajian dan Perbincangan \\ Profil Responden Kajian}

Kajian penilaian pelaksanaan PF pengajaran al-Quran di sekolah-sekolah ugama melibatkan satu kumpulan responden dalam kalangan guru al-Quran. Respoden terdiri daripada guru yang mengajar al-Quran di sekolahsekolah ugama. Dapatan profil responden diperolehi daripada satu set soal selidik yang telah diedarkan kepada responden di 43 buah sekolah ugama di NBD yang melaksanakan PF pengajaran al-Quran yang menjadi lokasi kajian.

\section{Profil Guru al-Quran}

Dapatan profil guru meliputi lokasi, jantina, umur, tahap akademik, kelayakan ikhtisas perguruan dan pengalaman mengajar al-Quran. Dapatan kajian ini dapat dilihat dalam jadual-jadual berikut:

Jadual 1 - Taburan responden mengikut lokasi sekolah

\begin{tabular}{ccc}
\hline Lokasi & Kekerapan & Peratus \\
\hline Bandar & 80 & 39.8 \\
Luar Bandar & 121 & 60.2 \\
\hline Jumlah & 201 & 100
\end{tabular}

Jadual 1 menunjukkan taburan responden mengikut lokasi sekolah. Hasil kajian mendapati seramai 201 orang guru yang mengajar al-Quran yang terlibat dalam kajian ini iaitu 80 orang (39.8\%) dari sekolah kawasan bandar dan 121 orang $(60.2 \%)$ dari sekolah kawasan luar bandar. Ini menunjukkan sekolah kawasan luar bandar mendominasi dalam kajian ini.

Jadual 2 - Taburan responden mengikut daerah

\begin{tabular}{ccc}
\hline Daerah & Jumlah Sekolah & Jumlah Responden \\
\hline Brunei Muara & $27(62.8 \%)$ & $139(69.2 \%)$ \\
Belait & $5(11.6 \%)$ & $47(23.4 \%)$ \\
Tutong & $3(7.0 \%)$ & $7(3.5 \%)$ \\
Temburong & $8(18.6 \%)$ & $8(3.9 \%)$ \\
\hline Jumlah & $43(100.0 \%)$ & 201 \\
\hline
\end{tabular}


Jadual 2 menunjukkan taburan responden mengikut daerah. Hasil kajian mendapati seramai 139 orang (69.2\%) dari sekolah-sekolah ugama Daerah Brunei Dan Muara, 47 orang (23.4\%) dari sekolah-sekolah ugama Daerah Belait, 7 orang (3.5\%) dari sekolah-sekolah ugama Daerah Tutong, 8 orang (3.9\%) dari sekolah-sekolah ugama Daerah Temburong. Ini menunjukkan responden dari sekolah-sekolah ugama Daerah Brunei dan Muara adalah lebih ramai dari sekolah-sekolah ugama daerah lain.

Jadual 2 menunjukan jumlah sekolah yang terlibat mengikut daerah. Dari 43 buah sekolah ugama, 27 buah (62.8\%) sekolah ugama dari Daerah Brunei dan Muara, 8 buah (18.6\%) sekolah ugama dari Daerah Temburong, 5 buah (11.6\%) sekolah ugama dari Daerah Belait dan 3 buah $(6.9 \%)$ sekolah ugama dari Daerah Tutong. Ini menunjukkan kebanyakan sekolah-sekolah ugama yang terlibat dalam kajian ini adalah sekolah ugama dari Daerah Brunei dan Muara.

Jadual 3 - Taburan responden mengikut jantina

\begin{tabular}{ccc}
\hline Jantina & Kekerapan & Peratus \\
\hline Lelaki & 68 & 35.3 \\
Perempuan & 130 & 64.7 \\
\hline Jumlah & 201 & 100 \\
\hline
\end{tabular}

Jadual 3 menunjukkan taburan responden mengikut jantina. Hasil kajian mendapati seramai 68 orang (35.3\%) adalah guru lelaki manakala guru perempuan 130 orang (64.7\%). Ini menunjukkan guru perempuan mendominasi jumlah guru lelaki yang melaksanakan PF pengajaran al-Quran.

Jadual 4 - Taburan responden mengikut status kelulusan akademik

\begin{tabular}{lcc}
\hline \multicolumn{1}{c}{ Akademik Tertinggi } & Kekerapan & Peratus \\
\hline Sarjana Pendidikan Perguruan Ugama & 5 & 2.5 \\
Sarjana Muda & 41 & 20.4 \\
Diploma Tertinggi Perguruan & 26 & 17.4 \\
Sijil Latihan Perguruan & 129 & 63.7 \\
\hline \multicolumn{1}{c}{ Jumlah } & 201 & 100.0 \\
\hline
\end{tabular}

Jadual 4 menunjukkan taburan responden mengikut status kelulusan akademik. Dari aspek latar belakang tahap akademik guru, 5 orang $(2.5 \%)$ adalah guru yang mendapat pendidikan peringkat sarjana pendidikan perguruan ugama, 41 orang $(20.4 \%)$ peringkat ijazah sarjana muda, 26 orang (17.4\%) peringkat diploma tertinggi perguruan dan 128 orang (63.7\%) guru mempunyai kelayakan sijil latihan perguruan. Ini menunjukkan kebanyakan guru dalam kajian ini adalah lepasan dari sijil latihan perguruan ugama. Secara umumnya, kebanyakan guru telah menjalani latihan dalam perguruan ugama di institusi perguruan di negara ini termasuk dalam menilai pencapaian pelajar di dalam bilik darjah.

\section{Jadual 5 - Taburan responden mengikut status kelayakan ikhtisas}

\begin{tabular}{lcc}
\hline \multicolumn{1}{c}{ Kelayakan Ikhtisas } & Kekerapan & Peratus \\
\hline Sarjana Muda Pendidikan & 23 & 11.4 \\
Diploma Perguruan Ugama Lepasan Ijazah & 2 & 1.0 \\
$\quad$ (DPULI) & 19 & 9.5 \\
Diploma Tertinggi Perguruan & 4 & 2.0 \\
Diploma Pengajian & 167 & 74.1 \\
Sijil Latihan Perguruan & 201 & 100.0 \\
\hline \multicolumn{1}{c}{ Jumlah } &
\end{tabular}

Jadual 5 menunjukkan taburan responden mengikut status kelayakan ikhtisas. Kajian mendapati kelayakan ikhtisas perguruan pula mendapati majoritinya iaitu 167 orang $(74.1 \%)$ mempunyai kelayakan ikhtisas perguruan. Hanya 23 orang (11.4\%) mempunyai Ijazah sarjana muda pendidikan, 19 orang (9.5\%) mempunyai kelayakan ikhtisas diperingkat diploma tertinggi perguruan, 4 orang $(2 \%)$, dan hanya 2 orang (1\%) saja mempunyai kelayakan ikhitisas di peringkat diploma perguruan ugama lepasan ijazah (DPULI). Secara umumya peratusan terbesar guru yang melaksanakan PF pengajaran al-Quran adalah guru yang memiliki sijil latihan perguruan (74.1\%). 
Jadual 6 - Taburan responden mengikut status pengalaman mengajar

\begin{tabular}{ccc}
\hline Pengalaman Mengajar & Kekerapan & Peratus \\
\hline 1-5 Tahun & 30 & 14.9 \\
6-10 Tahun & 62 & 30.9 \\
11-15 Tahun & 54 & 26.9 \\
20 Tahun keatas & 55 & 27.3 \\
\hline Jumlah & 201 & 100.0 \\
\hline
\end{tabular}

Jadual 6 menunjukkan taburan responden mengikut status pengalaman mengajar. Kajian mendapati pengalaman mengajar guru al-Quran adalah 62 orang (30.9\%) mempunyai pengalaman mengajar al-Quran 6-10 tahun, 55 orang $(27.3 \%)$ mempunyai pengalaman mengajar 20 tahun keatas tahun, 54 orang $(26.9 \%)$ mempunyai pengalaman 6 hingga 11-15 tahun dan hanya 30 orang (14.9\%) yang mempunyai pengalaman 1-5 tahun. Oleh yang demikian dapatan kajian ini menunjukkan bahawa majoriti guru mempunyai pengalaman dalam mengajar alQuran dan secara umumnya boleh mentaksir pelajarnya dalam pembelajaran al-Quran.

Jadual 7- Taburan responden mengikut status jawatan dan tugas di sekolah

\begin{tabular}{|c|c|c|}
\hline Jawatan dan Tugas di Sekolah & Kekerapan & Peratus \\
\hline Guru Besar & 3 & 1.5 \\
\hline Guru Kanan Akademik & 9 & 4.5 \\
\hline Guru Kanan Pentadbiran & 9 & 4.5 \\
\hline Guru Kanan al-Quran & 27 & 11.5 \\
\hline Lain-lain & 154 & 76.6 \\
\hline Jumlah & 201 & 100 \\
\hline
\end{tabular}

Jadual 7 menunjukkan taburan responden mengikut status jawatan dan tugas di sekolah. Kajian mendapati 27 orang $(11.5 \%)$ guru al-Quran bertugas sebagai guru kanan al-Quran, 9 orang (4.5\%) sebagai guru kanan akademik, 9 orang $(4.5 \%)$ sebagai guru kanan pentadbiran, 3 orang (1.5\%) sebagai guru besar dan 154 orang (76.6) bertugas sebagai guru biasa. Ini menunjukkan kebanyakan guru al-Quran bertugas sebagai guru al-Quran sepenuh masa tanpa komitmen dengan tugas sampingan dalam bidang pentadbiran atau akademik.

Jadual 8 - Taburan responden mengikut status perkhidmatan

\begin{tabular}{lcc}
\hline Jawatan dan Tugas di Sekolah & Kekerapan & Peratus \\
\hline Guru Ugama Terlatih & 168 & 80.6 \\
Pegawai Pelajaran & 35 & 17.4 \\
\hline Jumlah & 201 & 100 \\
\hline
\end{tabular}

Jadual 8 menunjukkan taburan responden mengikut status perkhidmatan. Kajian mendapati 168 orang (80.6 $\%)$ guru al-Quran berjawatan guru ugama terlatih dan 35 orang (17.4\%) berjawatan pegawai pelajaran. Ini menunjukkan kebanyakan guru al-Quran berjawatan sebagai guru ugama terlatih.

Kesimpulan daripada dapatan profil guru yang melaksanakan PF pengajaran merupakan guru yang mempunyai kelayakan dalam bidang akademik dan aspek kelayakan ikhtisas dalam perguruan. Begitu juga dengan aspek pengalaman dalam mengajar al-Quran merupakan aspek penentu di dalam kejayaan pelaksanaan PF pengajaran al-Quran juga perlu diperkukuhkan. Gabungan kelayakan akademik, kelayakkan ikhtisas perguruan dan aspek pengalaman akan dapat menentukan kejayaan dan kualiti pelaksanaan PF pengajaran al-Quran.

\section{Dapatan Kajian Deskriptif}

Tahap kemahiran Guru dalam Pentaksiran Formatif semasa PdP al-Quran

Jadual 9 - Kemahiran guru dalam PF semasa PdP al-Quran

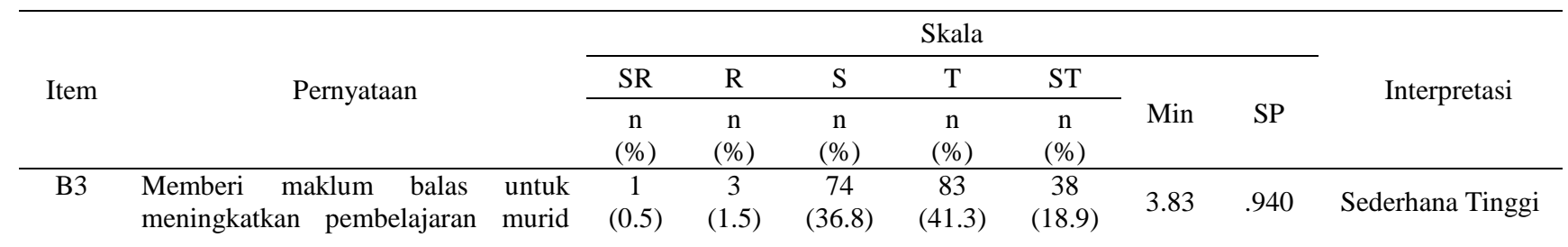




\begin{tabular}{|c|c|c|c|c|c|c|c|c|c|}
\hline \multirow[b]{2}{*}{ B11 } & \multicolumn{9}{|l|}{ dalam al-Quran. } \\
\hline & $\begin{array}{l}\text { Membimbing murid mengenal pasti } \\
\text { kekuatan dalam pembelajaran untuk } \\
\text { tingkatkan motivasi. }\end{array}$ & $\begin{array}{c}0 \\
(0)\end{array}$ & $\begin{array}{l}4 \\
(2)\end{array}$ & $\begin{array}{c}69 \\
(34.3)\end{array}$ & $\begin{array}{c}91 \\
(45.3)\end{array}$ & $\begin{array}{c}36 \\
(17.9)\end{array}$ & 3.82 & .835 & Sederhana Tinggi \\
\hline B6 & $\begin{array}{l}\text { Membuat pemerhatian PdP al-Quran } \\
\text { (terhadap interaksi, tingkah laku, } \\
\text { proses dan hasil kerja murid) }\end{array}$ & $\begin{array}{c}4 \\
(2)\end{array}$ & $\begin{array}{c}6 \\
(3)\end{array}$ & $\begin{array}{c}86 \\
(42.3)\end{array}$ & $\begin{array}{c}79 \\
(39.3)\end{array}$ & $\begin{array}{c}26 \\
(12.9)\end{array}$ & 3.58 & .827 & Sederhana Tinggi \\
\hline B5 & $\begin{array}{l}\text { Memadankan strategi PdP al-Quran } \\
\text { dengan tahap kebolehan murid secara } \\
\text { individu. }\end{array}$ & $\begin{array}{c}5 \\
(2.5)\end{array}$ & $\begin{array}{c}3 \\
(1.5)\end{array}$ & $\begin{array}{c}94 \\
(46.8)\end{array}$ & $\begin{array}{c}77 \\
(38.3)\end{array}$ & $\begin{array}{c}22 \\
(10.9)\end{array}$ & 3.54 & .806 & Sederhana Tinggi \\
\hline B10 & $\begin{array}{l}\text { Menggunakan maklumat PF untuk } \\
\text { membuat perancangan pengajaran } \\
\text { akan datang. }\end{array}$ & $\begin{array}{c}1 \\
(0.5)\end{array}$ & $\begin{array}{l}13 \\
(6.5)\end{array}$ & $\begin{array}{c}91 \\
(45.3)\end{array}$ & $\begin{array}{c}81 \\
(40.3)\end{array}$ & $\begin{array}{l}14 \\
(7)\end{array}$ & 3.50 & .837 & Sederhana Tinggi \\
\hline B7 & $\begin{array}{l}\text { Mencatat maklumat } \quad \text { hasil } \\
\text { pemerhatian dilaksanakan } \\
\text { sistematik dalam PdP al-Quran }\end{array}$ & $\begin{array}{c}4 \\
(2)\end{array}$ & $\begin{array}{c}7 \\
(3.5)\end{array}$ & $\begin{array}{c}98 \\
(48.8)\end{array}$ & $\begin{array}{c}69 \\
(34.3)\end{array}$ & $\begin{array}{c}23 \\
(11.4)\end{array}$ & 3.50 & .819 & Sederhana Tinggi \\
\hline B2 & $\begin{array}{lll}\text { Membina } & \text { aktiviti supaya } & \text { selari } \\
\text { dengan } & \text { standard/objektif } & \text { yang } \\
\text { hendak dicapai. } & & \end{array}$ & $\begin{array}{c}0 \\
(0)\end{array}$ & $\begin{array}{l}10 \\
(5)\end{array}$ & $\begin{array}{c}117 \\
(58.2)\end{array}$ & $\begin{array}{c}58 \\
(28.9)\end{array}$ & $\begin{array}{l}16 \\
(8)\end{array}$ & 3.40 & .708 & Sederhana Tinggi \\
\hline B4 & $\begin{array}{l}\text { Mengadakan aktiviti PF semasa PdP } \\
\text { al-Quran }\end{array}$ & $\begin{array}{c}5 \\
(2.5)\end{array}$ & $\begin{array}{l}12 \\
(6)\end{array}$ & $\begin{array}{c}97 \\
(48.3)\end{array}$ & $\begin{array}{c}73 \\
(36.3)\end{array}$ & $\begin{array}{l}14 \\
(7)\end{array}$ & 3.39 & .806 & Sederhana Tinggi \\
\hline B9 & $\begin{array}{l}\text { Mengurus maklumat pentaksiran } \\
\text { dengan bersistematik dalam PdP al- } \\
\text { Quran. }\end{array}$ & $\begin{array}{c}5 \\
(2.5)\end{array}$ & $\begin{array}{c}13 \\
(6.5)\end{array}$ & $\begin{array}{c}102 \\
(50.7)\end{array}$ & $\begin{array}{c}71 \\
(35.3)\end{array}$ & $\begin{array}{l}10 \\
(5)\end{array}$ & 3.34 & .778 & Sederhana Tinggi \\
\hline B8 & $\begin{array}{l}\text { Menginterpertasi hasil pemerhatian } \\
\text { untuk memberi skor (penguasaan) } \\
\text { dalam PdP al-Quran berdasarkan } \\
\text { standard prestasi. }\end{array}$ & $\begin{array}{c}4 \\
(2)\end{array}$ & $\begin{array}{l}10 \\
(5)\end{array}$ & $\begin{array}{c}112 \\
(55.7)\end{array}$ & $\begin{array}{c}65 \\
(32.3)\end{array}$ & $\begin{array}{l}10 \\
(5)\end{array}$ & 3.33 & .737 & Sederhana Tinggi \\
\hline B1 & $\begin{array}{l}\text { Merancang aktiviti PF untuk } \\
\text { diaplikasikan dalam proses PdP al- } \\
\text { Quran. }\end{array}$ & $\begin{array}{c}4 \\
(2)\end{array}$ & $\begin{array}{c}20 \\
(10)\end{array}$ & $\begin{array}{c}107 \\
(53.2)\end{array}$ & $\begin{array}{c}60 \\
(29.9)\end{array}$ & $\begin{array}{l}10 \\
(5)\end{array}$ & 3.26 & .783 & Sederhana Tinggi \\
\hline & Min Keseluruhan & & & & & & 3.50 & .606 & Sederhana Tinggi \\
\hline $\begin{array}{r}\mathrm{N}=2 \\
\text { Petun } \\
1 \\
2 \\
3 \\
4\end{array}$ & $\begin{array}{l}\text { Sangat Rendah }- \text { SR } \\
\text { Rendah - R } \\
\text { Sederhana - S } \\
\text { Tinggi - T }\end{array}$ & & & & 5. $S$ & gat Til & - ST & & \\
\hline
\end{tabular}

Jadual 9 menunjukkan taburan peratusan dan keputusan min aspek kemahiran guru dalam PF semasa PdP al-Quran di bilik darjah. Berdasarkan kepada Jadual 4.10, aspek kemahiran guru dalam memberi maklum balas untuk meningkatkan pembelajaran murid dalam al-Quran menunjukkan item tersebut berada di tahap yang sederhana tinggi, iaitu tinggi dan sangat tinggi seramai $79.3 \%$ (121 orang), purata min $=3.83$. Data ini menunjukkan sebahagian besar responden guru menyatakan bahawa memberi maklum balas untuk meningkatkan pembelajaran murid menjadi amalan PF di bilik darjah. Manakala taburan peratusan dari item B11 (membimbing murid mengenal pasti kekuatan dalam pembelajaran untuk tingkatkan motivasi) responden guru menyatakan seramai $63.2 \%$ (127 orang), purata min 3.82, guru melaksanakan bimbingan dan menggalakkkan murid untuk terus belajar al-Qur'an. Ini menunjukkan sebilangan kecil sahaja guru yang kurang memberikan maklum balas, iaitu seramai 2\% (4 orang) dan membimbing pelajarnya dalam pembelajaran al-Qur'an, iaitu seramai 2\% (4 orang). Data ini menunjukkan sebahagian besar responden guru menyatakan guru memberi maklum balas untuk meningkatkan pembelajaran murid dan membimbing murid mengenal pasti kekuatan dalam pembelajaran untuk tingkatkan motivasi khususnya apabila melaksanakan PF dalam pengajaran al-Quran di bilik darjah.

Begitu juga dari aspek kemahiran guru membuat pemerhatian PdP al-Quran terhadap interaksi, tingkah laku, proses dan hasil kerja murid, iaitu B6, keputusan skor min menunjukkan item tersebut berada di tahap sederhana tinggi (min=3.58) sahaja yang tinggi dan sangat tinggi, menjadi mahir dalam membuat pemerhatian PdP al-Quran terhadap interaksi, tingkah laku, proses dan hasil kerja murid semasa pelaksanaan PF guru dalam pengajaran al-Quran. Oleh itu data ini menunjukkan sebahagian responden guru menyatakan bahawa guru mahir melaksanakan PF berkaitan pemerhatian dalam proses PdP al-Quran terhadap interaksi, tingkah laku, proses dan hasil kerja murid dalam pengajaran al-Qur'an, iaitu seramai 52.2\% (105 orang). Sebahagian guru sahaja yang kurang mahir melaksanakan pemerhatian semasa melaksanakan PF dalam pengajaran al-Quran, iaitu 5\% (10 orang) dan 42.3\% (86 orang).

Pelaksanaan PF guru pengajaran al-Qur'an di bilik darjah berkaitan dengan kemahiran guru memadankan strategi PdP al-Quran dengan tahap kebolehan murid secara individu, iaitu B5, skor min menunjukkan item ini berada di tahap yang sederhana tinggi min=3.54 atau seramai 48.9\% (99 orang) responden guru menyatakan guru tinggi dan sangat 
tinggi mahir melaksanakan PF dalam pengajaran al-Quran dengan memadankan strategi PdP al-Quran dengan tahap kebolehan murid secara individu. Oleh yang demikian, daripada data ini dapat dilihat sebahagian besar responden guru menyatakan bahawa dalam pengajaran tilawah al-Quran, kebanyakan guru mahir memadankan strategi PdP al-Quran dengan tahap kebolehan murid secara individu meskipun ada sebahagiannya kurang mahir melaksanakannya dalam PF pengajaran al-Quran.

Selain itu, aspek kemahiran guru menggunakan maklumat PF untuk membuat perancangan pengajaran akan datang, iaitu B10, keputusan min menunjukkan item tersebut berada pada tahap sederhana tinggi, min=3.50 atau seramai $47.3 \%$ (95 orang) tinggi dan sangat tinggi, guru mahir menggunakan maklumat PF untuk membuat perancangan pengajaran akan datang. Walau bagaimanapun, ada sebahagian guru kurang mahir menggunakan maklumat PF untuk membuat perancangan pengajaran akan datang dengan jumlah kekerapan bagi sangat rendah dan rendah, $7 \%$ (14 orang) dan sederhana, $45.3 \%$ (91 orang).

Manakala taburan peratusan menunjukkan seramai 45.7\% (92 orang) daripada responden guru menyatakan tinggi dan sangat tinggi sahaja guru mahir mencatat maklumat hasil pemerhatian dilaksanakan secara sistematik dalam PdP al-Quran di bilik darjah, iaitu B7. Oleh itu, data ini menunjukkan sebahagian besar responden guru menyatakan kemahiran ini jarang digunakan dalam PF pengajaran al-Quran.

Dari segi aspek kemahiran membina aktiviti supaya selari dengan standard/objektif yang hendak dicapai, iaitu B2, dapatan kajian menunjukkan skor min item tersebut berada pada tahap sederhana tinggi min=3.40. Seramai $36.9 \%$ (74 orang) sahaja responden guru menyatakan guru tinggi dan sangat tinggi mahir membina aktiviti supaya selari dengan standard/objektif yang hendak dicapai. Manakala taburan peratusan menunjukkan seramai 5\% (10 orang) daripada responden guru menyatakan guru sangat rendah mahir membina aktiviti supaya selari dengan standard/objektif yang hendak dicapai. Data ini menunjukkkan bahawa guru sederhana mahir membina aktiviti supaya selari dengan standard/objektif yang hendak dicapai, iaitu seramai $58.2 \%$ (117 orang).

Aspek kemahiran mengadakan aktiviti PF semasa PdP al-Quran, iaitu B4, dapatan min menunjukkan item tersebut berada pada tahap yang sederhana tinggi min $=3.39$. Manakala taburan peratusan menunjukkan seramai $43.3 \%$ daripada responden guru menyatakan pengajaran al-Qur'an dengan mengadakan aktiviti PF semasa PdP al-Quran, tinggi dan sangat tinggi. Oleh itu, data ini menunjukkan sebahagian besar responden guru menyatakan kemahiran ini pada tahap sederhana tinggi sahaja dalam pelaksanaan PF pengajaran al-Qur'an.

Aspek mengurus maklumat pentaksiran dengan bersistematik dalam PdP al-Quran, iaitu B9, taburan peratusan menunjukkan seramai $40.3 \%$ (80 orang) daripada responden guru menyatakan pengajaran al-Quran tinggi dan sangat tinggi sahaja menggunakan teknik ini. Keputusan min item B9 berada pada tahap sederhana tinggi, min $=3.34$. Dengan lain perkataan, data ini menunjukkan sebahagian responden guru menyatakan guru al-Quran ada mengurus maklumat pentaksiran dengan bersistematik dalam PdP al-Quran bagi keperluan perancangan dimasa akan datang. Walau bagaimanapun, ada juga segelintir lagi kurang melaksanakannya, iaitu sangat rendah dan rendah $9 \%$ (18 orang) dan sederhana $50.7 \%$ (102 orang).

Aspek kemahiran menginterpertasi hasil pemerhatian untuk memberi skor (penguasaan) dalam PdP al-Quran berdasarkan standard prestasi, iaitu item B8, keputusan min menunjukkan item tersebut berada pada tahap yang sederhana tinggi min=3.33. Manakala taburan peratus menunjukkan seramai $38.3 \%$ (75 orang) daripada responden guru menyatakan pengajaran tilawah Al-Qur'an tinggi dan sangat tinggi mempunyai kemahiran menginterpertasi hasil pemerhatian untuk memberi skor (penguasaan) dalam PdP al-Quran berdasarkan standard prestasi. Oleh itu, data ini menunjukkan sebahagian kecil responden guru menyatakan guru mahir menginterpertasi hasil pemerhatian untuk memberi skor (penguasaan) dalam PdP al-Quran berdasarkan standard prestasi, manakala yang lain menyatakan sebaliknya.

Aspek kemahiran merancang aktiviti PF untuk diaplikasikan dalam proses PdP al-Quran, iaitu item B1, keputusan min menunjukkan item tersebut berada pada tahap yang sederhana tinggi, iaitu min=3.26. Manakala taburan peratusan menunjukkan 34.9\% (70 orang) daripada responden guru menyatakan tinggi dan sangat tinggi sahaja guru mahir merancang aktiviti PF untuk diaplikasikan dalam proses PdP al-Quran. Oleh itu, data ini menunjukkan sebahagian besar responden guru menyatakan guru mempunyai kemahiran yang sederhana dalam merancang aktiviti PF untuk diaplikasikan dalam proses PdP al-Quran, iaitu berada taburan peratus 53.2\% (107 orang) dan kurang mahir pada $12 \%$ (24 orang).

Kesimpulan, kemahiran guru dalam PF semasa PdP al-Quran keseluruhan keputusan min menunjukkan semua item berada di tahap yang sederhana tinggi. Data ini menunjukkan kemahiran guru dalam PF semasa PdP al-Quran pada aspek kemahiran memberi maklum balas untuk meningkatkan pembelajaran murid dalam al-Quran adalah tinggi dengan keputusan skor min 3.82. Manakala yang kurang mahir menurut daripada sebahagian responden guru adalah kemahiran merancang aktiviti PF untuk diaplikasikan dalam proses PdP al-Quran dengan keputusan skor min 3.26.

Keputusan min bagi 11 item keseluruhannya, berada pada tahap sederhana tinggi, min=3.50. Dengan lain perkataan, dapatan kajian ini menunjukkan sebahagian besar responden guru menyatakan kemahiran guru dalam PF semasa PdP al-Quran berada pada tahap sederhana tinggi. Oleh itu data ini juga menunjukkan, kemahiran guru dalam PF semasa PdP al-Quran memerlukan kepada penambahbaikan, khususnya dalam melaksanakan PF pengajaran alQur'an, terutama mengaitkan kemahiran merancang aktiviti PF, kemahiran menginterpertasi hasil pemerhatian untuk 
memberi skor (penguasaan) dalam PdP al-Quran berdasarkan standard prestasi, kemahiran mengurus maklumat pentaksiran dengan bersistematik dalam PdP al-Quran dan kemahiran mengadakan aktiviti PF semasa PdP al-Quran.

\section{Kesimpulan}

Rumusan hasil kajian ini mendapati guru al-Quran perlu mempunyai kemahiran melaksanakan PF dari semua aspek termasuklah merancang, membina, mengendali aktiviti pentaksiran dengan menggunakan pelbagai strategi dan kaedah, memberi maklum balas, membuat pemerhatian, mencatat maklumat, menginterprestasi maklumat, mengurus maklumat dan menggunakan malumat serta membimbing murid bagi meningkatkan motivasi mereka.

Dapatan kajian menunjukkan kemahiran guru dalam PF semasa PdP al-Quran keseluruhan keputusan min menunjukkan semua item berada di tahap yang sederhana tinggi $(\mathrm{min}=3.50)$. Menguasai kemahiran melaksanakan PF amatlah penting dalam memastikan proses pelaksanaan tidak tersekat-sekat. Stiggins (2008) menyatakan guru yang menguasai kemahiran PF cekap melaksanakannya dalam proses PdP akan menjadi pentaksiran berjalan dengan lancar dan sistematik. Kajian menunjukkan kemahiran guru dalam PF semasa PdP al-Quran pada aspek kemahiran memberi maklum balas untuk meningkatkan pembelajaran murid dalam al-Quran adalah tinggi.

Aspek kemahiran guru dalam memberi maklum balas untuk meningkatkan pembelajaran murid dalam al-Quran menunjukkan item tersebut berada di tahap yang sederhana tinggi dan begitu juga aspek membimbing murid mengenal pasti kekuatan dalam pembelajaran untuk tingkatkan motivasi guru melaksanakan bimbingan dan menggalakkan murid untuk terus belajar al-Quran. Hasil kajian ini menunjukkan sebahagian besar responden guru menyatakan guru memberi maklum balas untuk meningkatkan pembelajaran murid dan membimbing murid mengenal pasti kekuatan dalam pembelajaran untuk tingkatkan motivasi khususnya apabila melaksanakan PF dalam pengajaran al-Quran di bilik darjah.

Kemahiran berkaitan PF dalam pengajaran al-Quran tidak hanya diperolehi semasa latihan perguruan semata-mata. Kemahiran PF diperolehi secara berterusan secara latihan praktikal melalui tunjuk cara yang betul serta perbincangan secara profesional antara guru-guru al-Quran. Latihan berkaitan PF harus dilihat dari perspektif yang lebih luas bagi menangai cabaran dari aspekmpemikiran dan kebolehan murid yang berbeza-beza, cabaran subjek dan psikologi dan kaedah pengajaran. Rumusan kajian Ginsburg (2009) terhadap cabaran PF dalam subjek matematik mendapati bahawa latihan yang berterusan berkaitan PF mengikut subjek di sekolah amat diperlukan supaya guru-guru boleh bertindak lebih berkesan menangani cabaran dari segi pemikiran dan kebolehan murid-murid. Beliau berpendapat bahawa kursus dalam perkhidmatan merupakan medium paling berkesan untuk memberikan input pengetahuan dan kemahiran guru berkaaitan PF dan pelaksanaan yang lebih efektif.

Menurut Azmil Hashim dan Jahidih Saili (2015), kelancaran bacaan dalam konteks pembacaan al-Quran adalah merujuk kepada keupayaan guru al-Quran dalam membaca al-Quran dalam tempo At-Tartil, al-Hadr, At-Tadwir dan At-Tahqiq dengan lancar. Untuk itu, kajian tersebut menjelaskan masalah tersebut dapat diatasi melalui proses pengulangan atau takrar (Al-Qabisi, 1955).

Dalam pengajaran al-Quran perlu dilaksanakan secara berulang agar isi pelajaran yang dipelajari tidak luput daripada ingatan dan penuh barakah, firman Allah Subhānahu Wa Ta'ālā:

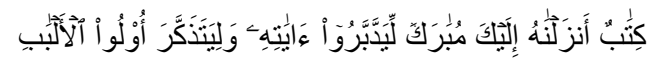

$$
\text { (سورة ص : (29) }
$$

Tafsirnya :

"Ini adalah sebuah kitab yang kami turunkan kepadamu penuh dengan berkah supaya mereka memperhatikan ayatayatnya dan supaya mendapat pelajaran orang-orang yang mempunyai fikiran"

(Surah $S \underline{a} d: 29)$

\section{Penghargaan}

Penulis ingin mengucapkan terima kasih kepada Fakulti Pendidikan, KUPU SB atas bantuan dan maklumat yang diberikan untuk memastikan kejayaan kajian ini.

\section{Rujukan}

[1] Kementerian Hal Ehwal Ugama. 2009. Mushaf Brunei Darussalam. Brunei: Jabatan Percetakan Negara.

[2] Al-Hadis. http://sigir.uitm.edu.my/webhadis/

[3] Adel M.Abdul Aziz. 2006. Panduan dan Bimbingan Guru al-Quran. Kuala Lumpur: YADIM.

[4] Al-Qabisi, Abi Hasan Ali Muhammad Khalaf. 1955. Ar-Risalah al-Mufassolah li ahwal al- muacallimin wa ahkam al-muacallimin wal mutacalimin. Kaherah: Dar Ehya' al-Kutub alcArabiyyah

[5] Azmil Hashim. 2010. Penilaian Pelaksanaan Kurikulum Tahfiz Al-Quran Di Darul Quran Jakim Dan Maahad Tahfiz Al-Quran Negeri. Tesis Ph.D, Universiti Kebangsaan Malaysia 
[6] Azmil Hashim dan Jahidih Saili. 2015. Hubungan antara Tahap Kemahiran Al-Quran Guru dan Pencapaian Tajwid Al-Quran Pelajar KKQ di Wilayah Persekutuan Kuala Lumpur. Tinta Artikulasi Membina Ummah 1(1), 2015. hlm. $144-151$

[7] Bahagian al-Quran, Jabatan Pengajian Islam. 2006. Garis Panduan Pelaksanaan Sistem Pengajaran al-Quran Berkategori. Bandar Seri Begawan: Jabatan Pengajian Islam

[8] Black, P. \& Wiliam, D. 2006. Inside the black box: Raising standards through classroom assessment: Granada Learning

[9] Black, P. \& Wiliam, D. 2008. Assessment in Education: Principles, Policy \& Practice. Assessment in Learning. Vol. 5. Hlm. 1. London: Routledge

[10] Brookhart, S. M. 2007. Expending views about formative classroom assessment: A review of the literature. In. McMillan J. H. (Eds.). Formative classroom assessment: Theory into practice, 43-62. New York: Teachers College Press

[11] Chappuis, S. \& Chappuis, J. 2008. The Best Value in Formative Assessment. Informative Assessment. 65 (4), hlm. 14-19

[12] Chua Yan Piaw. 2006. Kaedah dan statistik penyelidikan. Malaysia: Mc. Graw Hill Sdn Bhd

[13] Ginsburg, H. (2009). The Challenge of Formative Assessment in Mathematics Education: Children's Minds, Teachers' Minds. Human Development, 52(2), 109-128. https://doi.org/10.1159/000202729

[14] Hall, K. \& Burke W. M. 2003. Making formative assessment work: Effective practice in the primary classroom. Maidenhead: Open University Press

[15] Haron Din \& Sobri Salamon. 1987. Masalah pendidikan di Malaysia. Petaling Jaya: AlRahmaniah. Jabatan Pendidikan Islam dan Moral, KPM. (2005). Kurikulum Kelas Khas Kemahiran Membaca dan Menghafaz alQuran. Putrajaya. Bahagian Kurikulum Pendidikan dan Moral

[16] Ibnu Khaldun. 2000. Muqaddimah Ibnu Khaldun. Terj. Kuala Lumpur: Dewan Bahasa dan Pustaka

[17]Krejcie, R.V. \& Morgan,D.W. 1970. Determining sample size for research activities. Educational and Psychological Measurement, 30: 608-619

[18] Mohamad Azhar Mat Ali \& Shahrir Jamaluddin. 2007. Amalan pentaksiran untuk pembelajaran di sekolah menengah. Jurnal Pendidikan 2007, Jilid 27(1), 19-39.

[19] Misnan Jemali. 2008. Amalan Pengajaran Dan Pembelajaran Tilawah Alquran Sekolah-Sekolah Menengah. Tesis Ph.D, Fakulti Pendidikan Universiti Kebangsaan Malaysia.

[20] Mokhtar Ismail. 2009. Pentaksiran pendidikan. Kuala Lumpur: Dewan Bahasa dan Pustaka

[21] Na'imah Ishak. 2011. School based assessment as transformation in educational assessment. Keynote dalam International Seminar on Measurement and Evaluation (ICMEE 4) USM, Pulau Pinang, 9-12 Oktober

[22] Norwati Haji Abu Bakar. 2019. Pengaruh Pentaksiran Kendalian Sekolah Untuk Pembelajaran (SBAFL) Terhadap Gaya Pengajaran dan Pembelajaran Dalam Pendidikan Islam di Negara Brunei Darussalam. Tesis PhD. Universiti Kebangsaan Malaysia

[23] Pinchok, N., \& Brandt, W. C. 2009. Connecting formative assessment research to practice: An introductory guide for educators. Learning Point Associates

[24] Roslan Haji Untong, Mokhtar Ismail, Hasan Manurung \& Mazne Haji Othman. 2011. Ketekalan Pemarkahan Oleh Penilai Di Dalam Ujian Asas Tilawah Al-Quran Pada Peringkat Sekolah Rendah International Conference And Exposition On Research In Islamic And Arabic Language Education 2011, Awana Porto Malai Resort, Langkawi, Kedah, Malaysia. 26-28 September 2011

[25] Roslan Haji Untong \& Manan Haji Osman. 2014. Sistem Pengajaran Al-Quran Berkategori: Satu Penilaian Awal. International Conference on Teachers Education 2014. 1-2 Safar 1436 Bersamaan 24-25 November 2014. Empire Hotel Brunei

[26] Roslan Haji Untong, Misnan Jemali \& Noor Shah Saad. 2017. Isu Dan Cabaran Pentaksiran Dalam Pengajaran Dan Pembelajaran Al-Quran. Seminar Nusantara Pendidikan al-Quran dan Kitab Turath 29-30 Rejab 1438 bersamaan 25-26 April 2017 di Dewan Tarbiyah KUPU SB

[27] Roslan Haji Untong, Misnan Jemali \& Noor Shah Saad. 2019. Amalan Pentaksiran Dalam Pengajaran Dan Pembelajaran al-Quran Di Sekolah-Sekolah Ugama Di Negara Brunei Darussalam - Satu Kajian Terhadap Pandangan Guru al-Quran. Seminar Penyelidikan Pasca Siswazah. 09-12 Rejab 1440 bersamaan 16-21 Mac 2019. Universiti Malang, Surabaya. Indonesia

[28] Stiggins, R. 2004. New assessment beliefs for a new school mission. Phi Delta Kappan, 86(1): 22-27 